\title{
Ethnic Factor of Unity or Political Division in Africa: Case of Congo Brazzaville from 1992 to 2015
}

\author{
Nzoussi Hilaire Kevin*, Oba Dominique, Sah Zéphirin \\ Marien Ngouabi University, Teacher Training College, Brazzaville, Congo \\ *Corresponding Author: Nzoussi Hilaire Kevin, Marien Ngouabi University, Teacher Training College, \\ Brazzaville, Congo
}

\begin{abstract}
The ethnic group is defined as a more or less wide group of men and women essentially characterized by linguistic and cultural traits (the language and the culture), and a strong sense of belonging to this community. The population of Congo is made up of several ethnic groups since the act generally Berlin which has contributed to the disappearance of kingdoms and chiefdoms. On the political terrain these different ethnic groups are tempted to fight for the management and control of political power. At their independence, the black African states in general and the Congo in particular in order to have an organization policy worthy of the name has calqued on the European model form of organization, thus the Congo established several institutions likely so that contribute to the good running of the country in which the army plays a role not negligible in the maintenance of peace and public order. The present e study aims to show the role of ethnicity as a factor of unity or political division in Africa based on the specific case of Congo from 1992 to 2015.
\end{abstract}

Keywords: Ethnic, army, power management, political, Congo Brazzaville

\section{INTRODUCTION}

The Berlin, conference which took place on 15 November 1884 to 26 February 1885, forced the people who once lived separately to live now together. This conference delimited the boundaries of what are today the African states. After their independence, the creation in 1963 including May 25, the Organization of the Unit African marked a decisive turning point in the organization it's of socalled states. For the first time since three years, the African states are grouped in an organization as African Republic where they are now discussing their problems. The Organization of the United African acknowledged those born boundaries of the act generally Berlin: it is the intangibility of borders .In 1960, when virtually all African states access to their independence, they adopted the single party. These states born of the dislocation of kingdoms and chiefdoms are of several ethnic groups that must now fraternize for the same cause and the same fate. To organize these new states, they are creating several institutions including the army .On the land policy; ethnic groups generally compete for the conquest of power politics. The army of itself has always played a role not negligible for the maintenance of peace and security. In this sense we will show if ethnicity is a factor of unity or political division in Africa based on the case of Congo

\section{THE NOTION OF ETHNICITY}

According to the Petit Larousse dictionary, ethnicity is defined as a human society deemed homogeneous, based on the conviction of sharing the same origin and on an effective community of language and culture. Ethnicity is also a group more or less wide of men and women characterized by traits mainly linguistic and cultural (language and culture), and a strong feeling of belonging to this community than of difference with neighboring groupings, or even opposition to them ${ }^{1}$.

Indeed, ethnicity is also characterized by relative links and the same organization. By this definition it is understandable that so these are people who have a common origin that is to -say the same history, the same language and the same culture who are proud to recognize members of the same ethnic

${ }^{1}$ Jean Bosco Anizock, 2007, mimeographed course on decolonization and problems of independent black Africa, CAPES IV, ENS, UMNG 
group. Since November 28, 1958, the date of the proclamation of the Republic, all political parties were created on the basis of tribal and ethnic considerations. The handing over of state power to local elites in 1958 by the colonial authority opens the era of identity violence ${ }^{2}$. The politician hides behind his ethnic group to demonize other ethnic groups who are at the origin of their misfortune. Each ethnic group seeks the conquest of power to assert itself in regard to others. It is in this sense that the historian Jean Pierre Thystère Tchicaya states:

The tribalism denounced in the Congo is still the tribalism of the other ${ }^{3}$.

Some sociologists who address the issue try to bring sharp opinions on the issue of ethnicities and the withdrawal of identity .This is the case of Henri Ossebi who made a thorough analysis of the speech of the Congolese Labor Party, founded by Marien Ngouabi, a native of the northern part of the Congo explains:

Jamming operates both by default and by excess. In the first case, it takes on the appearance of a denial; at no time does the official discourse designate the holders of power as tribalism or regionalist actors. It is always the others, in a language of wood, who constantly function to the exclusion and the accusation. In the second case, it consists in seeing everywhere, in any conflict or any competing claim, the figure of the ethnic group or the region 4 .

In the Republic of Congo since independence, ethnic groups have always clashed on several grounds (politics, occupation of space.) Ethnicity on these bases operates a dichotomous division of the world between the good (us) and the wicked the others he makes escape or fight for survival. The other, if it is not me, I want it to become or, it disappears. The promise of enrichment that represents the different other is not what we grasp first, in front of him ${ }^{5}$.

This is to say that ethnicity is at the center of both the conquest of power and the management of public affairs. Ethnic preoccupation gives rise to nepotism, regionalism and, later, tribalism. This is justified by the fact that the management of state-owned enterprises, management of administration and public affairs is based on ethnic and tribal bases. In consideration of all the above,

The sociologist Côme Mankassa thus speaks of a congenital tare in the management of power when he says:

When one is of the ethnicity of the President of the Republic, one has the impression to govern, to participate directly in the power. If Congo is bankrupt, it owes it to regionalism. National unity must be regarded not as a given but as a becoming ${ }^{6}$.

When he came to power in 1992, President of the Republic Pascal Lissouba made a crucial remark about ethnic groups when he said:

In our country, we were fighting at the bottom to gain power. And when a group took power, what was it? He appropriated property, equipment and others, and distributed them sparingly to others but copiously to those around him. .

Pascal Lissouba goes further by saying that: «The political struggles in the Congo are in fact only the struggles between the tribes, in order to conquer the state power and to establish their hegemony. The

\footnotetext{
${ }^{2}$ Dominique Ngoie Ngalla, 2003, The return of ethnic groups, which state for Africa ?, Paris, Bajag - meri , p.49

${ }^{3}$ Jean Pierre Thystère- Tchicaya, in Jeune Afrique l'Intelligent, No. 2029, November 30 to December 6, 1999, P.21.

${ }^{4}$ H. Ossebi, State and ethnicity in the Congo: new situations, old demons, in Revue de l'institute of sociology, No. 3-4, 1998, Brussels.

${ }^{5}$ D. Ngoie Ngalla, op.cit p. 83

${ }^{6}$ C. Mankassa, Head of Bankruptcy. Regionalism, in the Diplomatic World, August 1992, P.26.

${ }^{7}$ Pascal Lissouba, quoted by PD Mayoukou, in his memoir entitled Mediation in Armed Conflicts in the Republic of Congo from 1992 to 2001.ENAM. P. 20
} 
accession to power of an individual enshrines in fact the hegemony of the ethnic group from which the holder of supreme state power comes. This ethnic group ensures the control of the political, economic, social life of the country ${ }^{8 "}$

The ethnic groups compete not only on political grounds, but also land, even beyond death they refuse to make changing. It is thought that Dominique $\mathrm{N} g$ goose Ngalla in this paragraph

(...) the awareness of their uniqueness as a cultural community

is such that even at the time of colonial peace, beyond

even death, the ethnic groups refuse to mix. The distribution

of cemeteries ethnic groups when the geographical configuration

of urban space lend themselves in this respect very significant. Well

often such discriminatory practices justified without reservation or

moral reluctance of any kind by their authors as ranging from

itself, are far from being the result of conflict ${ }^{9}$

As it can be seen, ethnic groups are strongly represented in the cultural and social structures administrative. The Congolese political space is a confrontational confrontation of ethnic mores ${ }^{10}$. The philosopher Charles Zacharie Bowao has developed the concept of ethnocentrism which he says influences the collective consciousness of citizens by developing sometimes difficult and clumsy behaviors. He explains himself:

" (...) this ideological-political insolence, the Congo was led successively by Kongo (President Youlou), Lari (President Massamba-Debat), Kouyou ( PresidentsNgouabi and Yhombi- Opango ), Mbochi (President Sassou Nguesso), $N^{\prime}$ zebi drowned in the "NIBOLEK" (President Lissouba). The other ethnic groups who have accompanied the ethnic groups in power until then, wait, in turn, a reckless child of the soil succeeds in making its way to a national destiny to honor his own people. ${ }^{11 "}$ More far, he adds:

\section{When will the turn of Teke, Mbeti, Vili, Katangese, Djem, Bembe, etc.? ? Everything is combined in a low voice, nobody dares to say it high, for fear, it is said, to be indicted, then condemned for conspiracy against the security of the State ${ }^{12}$.}

The affirmation of ethnic groups as the dominant trend is often a source of problems encountered in the independent black African, as not being arrived at the stage of the United nations' are states of Black Africa have been designed on the basis of tribal and ethnic groups. Therefore, each ethnic group is always looking to assert its superiority in respect of the other, and ethnicities or ethnic groups that do not have management or monopoly of power are regarded as marginalized.

Since the proclamation of the Republic on 28 November 1958 until today the political history of the Republic of Congo has always been marked by wars repetition which firstly in 1959 opposed the Ngalla of Jacques Opangault and the lari of Fulbert Youlou. In 1990-1991 during the period of democratization led to the birth of new political divisions and the confirmation of the ethnic group.. That is why, during the national sovereign conference held in 1991, ethnic groups asserted themselves against each other.

- The PCT, former single party, faces the departure of several cadres, who create new parties ;

- UPADS, created by the PCT dissidents, the practices of this party will lead to an ethno-regional fundamentalism because of the implementation of the doctrine of the tribe - class dear to Pascal

\footnotetext{
${ }^{8}$ P. Lissouba, op. cit . P. 20

${ }^{9}$ D. NgoieNgalla, op.cit, p. 81

${ }^{10}$ Jean Didier Ngalebaye , 2018, Around the imposture ethnocentrism of Charles Zacharie Bowao, Douala, Ed.Cheikh Anta Diop , p. 115

${ }^{11} \mathrm{CZ}$ Bowao, 2014, The Ethnocentric Imposture, advocacy for an ethical argumentation of politics, Editions Hemar, Brazzaville, P. 39.

${ }^{12}$ Ibid
} 
Lissouba (doctrine of raising the rank ethnic groups, and to ensure the predominance of the two of them over the others).

- The MCDDI, whose leader Bernard Kolelas carrying a divine mission will also fight for access to power. He recruits activists particularly in its region of origin (the Pool).

These three major parties to name just a few (since there are many others: RDPS, RDD, UDF, UPSD ...) amplified ethnicity. Tribalism, regionalism and the ethnicity are more developed in Congo. It is therefore ultimately under the yoke of these three parties above that the Congo embarks on the path of democracy that will have very dramatic consequences on the political social and economic life of the nation in that the social fabric is more destroyed because of their egos. These ethnic parties or ethno parties derive their strength from the mobilizing power of ethnic members. These parties have deputies, senators and councilors (municipal or departmental) whose number is proportional to the ethnic preponderance of the voters ${ }^{13}$.

Yet colonization had pushed people to coexist, that are to live together and pool their efforts to build a common future and rid of ethnic and regional divisions. But the white man had forgotten that all blacks did not have the same culture and the same origins. The sociological and human problem was not taken into account. The Berlin Act appears as the main cause of the conflicts that tear the States of this part of black Africa today. ${ }^{14}$ Unfortunately, the arrival of democracy in the late 1990s exposed ethnic and tribal differences.

To better assert his power, President Pascal Lissouba set up the policy of regional groupings. Thus, the NIBOLEK (Niari, Bouenza and Lekoumou) was instituted. The ethnic prioritization was confirmed more or the men distributed in their terror, that is to say on the same territory, the same space and the same cultural area took charge of the management of public affairs. By creating tribal and ethnic political parties, Congolese politics helped to divide the country into an area of choice and influence.

\section{ETHNICITY CAUSES THE SUBDIVISION OF THE COUNTRY INTO TERRITORIES}

In 1993 when the second Congo war called the Nibo - Chek war broke out in 2002, the Republic of Congo was divided into three subsets that are:

The sub-state Niboleck, with territory, the regions of Niari, Bouenza and Lékoumou, with a population called Nibolek , a militia, Cocoyes and a state party, UPADS ;

- The sub-state Kongo- Tchek, with territory, the region of Pool, a population the Kongo called Tcheks ${ }^{15}$ by the Niboleks, a militia, the Ninjas and a state party, the MCDDI ;

- The sub-state composed of natives of the north and south of the country, with a militia, the Cobras and a state party, the PCT.

With the birth of these three sub-states, the representation of the Congolese nation had completely disappeared. This disappearance does not date from today, since colonization, Africans have not inherited nations, but rather states. The nation is a long-term construction. From 25 May 1963, when the Organization of African Unity was established, the policy of the inviolability of frontiers was maintained, that is to say, all the borders of the Berlin Conference were maintained. The independence of the states of black Africa. Only the territorial compensation policy was applied. It is in this context that Ernest Renan asserts about the nation the following:

A great solidarity constituted by the desire to live together, it is the consent, the clearly expressed wish to continue the common life, because of this, the individual acquires by the nation and within it, intellectual culture, productive power, safety and well-being. The civilization of the human race can not be conceived of and is possible only by means of civilization and the development of the nation ${ }^{16}$.

\footnotetext{
${ }^{13}$ CZ Bowao, 2014, op. Cit., PP 48-49.

${ }^{14}$ Dominique NgoieNgalla, 2003, op.cit , p.47

${ }^{15} \mathrm{Chek}$, anacronyme given to Laris by nationals of Niari countries. The Chek is a little bird that passes everywhere to suck the flowers.

${ }^{16}$ Extract from the speech given on March 11, 1882 at the Sorbonne.
} 
This is to say that ethnicity is at the center of economic and social political life in black Africa. In other words, ethnicity characterizes and paces the life of a nation. Ethnicity is at the center of all political life: political party political formation, electoral process, government stability ${ }^{17}$. It is in this context that some intellectuals of the Congo, let us say, most of the cadres of the country adhere to the political parties not on coherent programs of the parties, but rather on tribal and ethnic bases.

This tribal and ethnic concession entered the political history of Cong since the years 1958 .In fact, November 28, 1958, Mr. Yambot, while prominent part of the African Socialist Movement Jacques Opangault, and originating in the Pool region making party of the Kongo ethnic subgroup refuse to respect the instructions given by the Party by voting in favor of Fulbert Youlou of the same sub-ethnic group as himself. In the letter to a dead man, André M. evokes this by saying the following:

Member of the party of Jacques Opangault, the MSA, you preferred to
vote for Fulbert Youlou, because he was from the south, like you. Today,
you would be unhappy if you saw, the Niari man, the people of Pool to
oppose Pascal Lissouba to overthrow him. Pool officials are unable to
explain to theirs that power is not taken in this way, with the risk of civil
war that entails. Every day, the "Nibolek" are driven out of Bacongo,
but nobody from the Pool takes a stand against these attitudes, not even
the church ${ }^{18}$.

In fact, the cohabitation between the ethnic groups that were forced to live together by colonization is the result of clashes and multi-dimensional wars that are found in most states of black Africa. It is in this sense that Dominique Ngoïe Ngalla points out the following:

The identity violence came from the mutual intolerance of ethnic groups opposed by their traditions and cultures, and who resort massively to them to engage face to the threatened interests, is a sociological phenomenon jets in the history of Congo. It appears for the first time in the cities to the collision of independence (1946-1960), and even more clearly after independence, more clearly and recurrently after the Sovereign National Conference and the establishment of pluralist democracy to which the absence of an enlightened public opinion would make unforeseen turns take place, but perfectly understandable: the exacerbation of what is called an incorrect term, tribalism : the instrumentalization of in the face of specific, collective or so-called ${ }^{19}$.

\section{THE ETHNIC AND VERNACULAR NEOLOGISMS}

It must then be said that since the proclamation of the Republic, the nation-state dreamed of by the founding fathers has not existed to this day. The first bill appeared in the vote leading to independence or inter-ethnic interests took over at the expense of common interests. All the successive presidents at the head of the Republic of Congo relied on their ethnic groups to govern. In other words, each president in power struggles body and soul to satisfy first of all the members of the ethnicity of which he is a native, then the other ethnic groups. For example, during the reign of these various presidents at the head of the Congo, concepts that are at least patriotic and do not honor what is called a nation and a state have developed.

- Under the reign of Presidents Fulbert Youlou and Alphonse Massamba Debat, Lari and Kongo said: Beto na Beto, that is to say "We to us " ;

- The Mbochi under Sassou I allowed themselves to pronounce the following words: Lidza, Lignua, Ledzaraotsotsa ; which translates as : "We eat, we dance, we have fun anyhow" ;

- The day after President Pascal Lissouba came to power, the Bembé had the slogan: Ya me kumayabeto ; Ya ba anger, yabantsaye na bantsaye ; which means : " It's now our turn, no anger, but joy, nothing but joy ${ }^{20 "}$;

\footnotetext{
${ }^{17}$ Gabriel Bokoumaka, quoted by J. Koudissa, 2009, in Democracy, Constitution, Political Culture in Congo, Edilivre, Paris, P. 304

${ }^{18}$ African Week, No. 1964, P.6

${ }^{19}$ Dominique NgoieNgalla , 2003, op.cit, P.97

${ }^{20}$ Anicet Akanawene, op.cit, p.317
} 
- Mr. Sassou returned to power following the war of June 5, 1997, his entourage mbochi who found the " paradise " cry loudly that: Moro O bosso ${ }^{21}$; which means : " Have someone in front of or better yet, have a godfather".

Thus, the elementary principles of a state as well as democratic norms and principles are then flouted in favor of selfish interests whose primary objective is to keep the cost of power as long as possible. Other ethnic groups are relegated to the background. The functioning of the state apparatus and the management of large institutions of the country, financial offices and strategic positions both civil and military are mostly held by members of the ethnic group of the President of the Republic or ethnic groups related, that is to say close to the presidential race. This malevolent practice contributes negatively to the country's retreat. Yet the ethnic multiplicity and further racial wealth is an enormous wealth for a country that wants to get developed.

Clearly, the state personifies the nation and has the duty to forge it. But Congolese political actors maintain communalist and conflictual tensions based on several problems of the past. The fierce race for access to the supreme judiciary makes use of malevolent and undemocratic practices, thus helping to rekindle tensions and the tearing of the social fabric. This leads to nonconforming electoral practices, clashes, wars and problems of all kinds. Ethnic multiplicity in most countries of black Africa is a source of tension and repeated wars.

Finally, it should be pointed out that in the Republic of Congo since the proclamation of the Republic, until 2017, the ethnic groups do not cease fighting for conquest or recon quest and the management of political power. What appears as a settlement when a new ethnic group comes to power? This is why the practice of democracy itself is problematic and difficult as a whole. However, when one is elected to the supreme magistracy (president of the Republic), one is neither president of an ethnic group nor a region nor my still of a clan, because one can not become president of the Republic if is voted only by members of his ethnicity. We are then President of the Republic of all Congolese. Appointments to positions of civil and military responsibilities, the allocation of foreign scholarships to students, internships and recruitment in public and private administrations.... must be made on the basis of competence. The realization of the economic projects in such or department of Congo must not be influenced by the geographical situation, but rather by the state of need expressed by the locality or the said department.

\section{THE INFLUENCE OF THE MILITARY IN THE SETTLEMENT OF CRISES IN CONGO}

Since the proclamation of the country's independence in 1960, the military has always played a large role in the maintenance of peace, security and public order. It helped maintain political balance and unity in 1963, when President Fulbert Youlou was overthrown. In 1968, the army played a major role while the country was on the verge of implosion; Captain Marien Ngouabi then took over the management of the country. Marien Ngouabi's arrival in power marked a long reign of military in power.

During the sovereign national conference held in 1991, which had resulted in a new start of democracy in the Congo, the army had been truly impartial and had accompanied the speakers to the resolution of the problems. After that, the elaboration of a new constitution voted by the primary sovereign who was to regulate the life of the country in all areas. This constitution in its article 162 stipulated that: "The Public Force is apolitical. It is subject to the laws and regulations of the Republic. It is instituted in the general interest. No one can use it for any particular purpose ... "22.

Thus, during the unfortunate events of 1993 that culminated in the Bongo Nauara government's motion of censure, the country sank into chaos. The President of the Republic asked the army under

\footnotetext{
${ }^{21}$ The term "Congolese" refers to tribalism, regionalism and ethnocentrism, every time a Congolese President comes to power, those of his ethnic group, his region or his tribe pass high dignitaries as if the country were only them, no one outside their region and others. This behavior not only delays the country, but also plunges it into civil, tribal wars. The wars that occur in the Congo never exceed the tribal or ethnic space, if necessary that of February 1959 and those of the period post national sovereign conference. Also, very often they create a bipolarity of the country "north-south". If the Congolese could know that the President of the Republic was never for a region, an ethnic group or for a given tribe, but for the whole country and in the service of all the citizens of this country, we had to avoid certain problems which endanger the entire State.

${ }^{22}$ Article 162 of the Constitution of 15 March 1992
} 
the yoke of the Chief of Staff, in particular General Jean Marie Michel Mokoko, to intervene in order to maintain order and public safety. But the latter had disobeyed because respecting the constitution and lively by a patriotic spirit. What cost him his job. Meanwhile, the President of the Republic Professor Pascal Lissouba appealed to the Israelis to form his private militia called cocoyes. This body of cocoyes was called the ministerial reserve and was made public by the letter of the Head of State No. 756-PR / Cab-Civ of August 9, 1993. One of the men charged to form cocoyes in Abbeville in the Bouenza, one of the bastions of the President of the Republic Professor Pascal Lissouba states the following:

\section{We need the competence of the Israelis to establish democracy and practice $^{23}$.}

In addition to these cocoyes, he also had Zulus who came to reinforce the ranks of cocoyes who had for bastion 07 Mfilou Ngamaba district. Immediately the reaction of political opponents to Pascal Lissouba by Denis Sassou Nguesso occurrence and Bernard Kolelas also founded their private militia's cobras respectively for the first and between the Ninjas for the second opponent. Except for the ninjas, it was these private militias who clashed violently among themselves in the early hours of the civil war of 05 June 1997.

The army is dissected into small groups to cause ethnic partisanship; it was less effective end to the war .Most army officers originally from the northern part of the country had joined Denis Sassou Nguesso and south of Country Pascal Lissouba. This reason is explained by the fact that ethnicity still influences the management of power in black Africa in general and in the Congo in particular. The war of June 5, 1997 had undermined the basic principles of democracy and had put in naked rancor of both in regard to other guard for many years.

Faced with the impotence of the army became bloodless to because of tribal and ethnic tomography, rebellion triumphed against the democratically elected president and who were considered incapable of maintaining security and public order in the country, and history Congolese politics has only stuttered since independence to the present day.

The army was in fact not in any case being used for political or personal purposes by politicians hungry for power. Unfortunately, the army seems to be turning away from its sovereign mission by serving the interests of politicians to whom it sometimes owes appointments and advancements on the honor roll of its cadres.

\section{CONCLUSION}

The democracy does not rhyme with culture ethnicity. The ethnicity becomes a source of unity policy if each actor to whatever level favors the interest generally to the detriment of the interest's supporter and isolationism.

The democracy in Africa and the Congo must to up a great challenge, one to complete the creation of a nation state in the same time it needs to develop a society healthy and active civil. This calls for impartial and balanced management of the conflicts that arise in terms of access to resources. Basically, the management of political power must be based on competences and not on the basis of identity and partisanship. The ethnic consciousness has sufficiently shown its limits in the management of public affairs in Africa and for us in the Congo.

\section{ACKNOWLEDGEMENTS}

Our thanks to everyone who provided any assistance for the drafting and translation of this scientific work.

\section{REFERENCES}

[1] Akanawene A., 2019, Les médiations des crises congolaises de 1958 à 2015, thèse de doctorat unique en histoire, UMNG,ronéo

[2] Anizock J. B, 2007, Cours polycopié sur la décolonisation et problèmes de l'Afrique noire indépendante, CAPES IV, ENS, UMNG, inédit

[3] Baniafouna (C.), 1995, Congo Démocratie ; Les Déboires de l'apprentissage, volume 1, éd.Paris, L’Harmattan,

\footnotetext{
${ }^{23}$ Baniafouna (C.), 1995, Congo Democracy; The Tips of Learning, Volume 1, ed. The Harmattan, Paris, P.121
} 
[4] Bowao C.Z., 2014, L'Imposture Ethnocentriste, plaidoyer pour une argumentation éthique du politique, les Editions Hemar, Brazzaville,.

[5] Constitution de la République du Congo du 15 mars 1992

[6] Gabriel Bokoumaka, cité par J. Koudissa, 2009, dans Démocratie, Constitution, Culture politique au Congo, Edilivre, Paris

[7] La Semaine Africaine, $n^{\circ} 202$ 1964,

[8] Mankassa C., 1992, Responsable de la faillite. Le régionalisme, in le Monde Diplomatique, août,

[9] Mayoukou P. D., 2008, dans son mémoire intitulé La médiation dans les conflits armés en République du Congo 1992 à 2001.ENAM.

[10] Ngalebaye J. D. 2018, Autour de l'imposture ethnocentrisme de Charles Zacharie Bowao, Douala, Ed .Cheikh Anta Diop,

[11] NgoieNgalla D., 2003, Le retour des ethnies, quel Etat pour l'Afrique ?, Paris, Bajag-meri,

[12] Ossebi H.1998, Etat et ethnie au Congo : nouvelles situations, vieux démons, in Revue de l'institut de sociologie, $n^{\circ} 3-4$, Bruxelles.

[13] Thystère-Tchicaya Jean Pierre, in Jeune Afrique l'Intelligent, ${ }^{\circ} 2029$, du 30 novembre au 6 décembre 1999

Citation: Nzoussi Hilaire Kevin*, Oba Dominique, Sah Zéphirin. "Ethnic Factor of Unity or Political Division in Africa: Case of Congo Brazzaville from 1992 to 2015". International Journal of Humanities Social Sciences and Education (IJHSSE), vol. 6, no. 10, 2019, pp. 38-45. doi: http://dx.doi.org/10.20431/23490381.0610004 .

Copyright: (C) 2019 Authors. This is an open-access article distributed under the terms of the Creative Commons Attribution License, which permits unrestricted use, distribution, and reproduction in any medium, provided the original author and source are credited. 